\title{
Assessment of the effect of nanomaterials on sediment-dwelling invertebrate Chironomus tentans larvae
}

\author{
P. J. Oberholster ${ }^{\mathrm{a}, \mathrm{b} \#}$, N. Musee ${ }^{\mathrm{a} \dagger \#}$, A-M. Botha ${ }^{\mathrm{c}}$, P. K. Chelule ${ }^{\mathrm{d}}$, W. W. Focke , $^{\mathrm{e}}$ \\ P. J. Ashton ${ }^{a}$
}

${ }^{a}$ CSIR Natural Resources and the Environment, P.O. Box 395, Pretoria 0001;

${ }^{\mathrm{b}}$ Department of Paraclinical Sciences, Faculty of Veterinary Science, University of Pretoria, P/Bag X04, Onderstepoort 0110, South Africa;

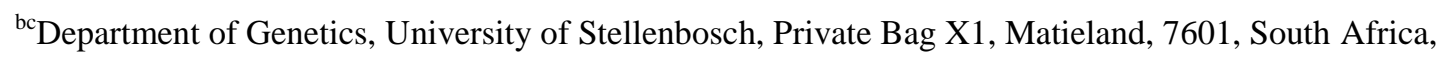
${ }^{\mathrm{d}}$ Department of Public Health, University of Limpopo, MEDUNSA Campus, MEDUNSA 0204, South Africa

${ }^{\mathrm{e}}$ Built Environment and Information Technology, University of Pretoria, Hillcrest, Pretoria, 0002, South Africa.

\begin{abstract}
Studies were conducted to determine the effects of a panel of seven nanomaterials (NMs), namely: $\alpha$-alumina, $\gamma$-alumina, precipitated silica; silica fume, calcined silica fume, colloidal antimony pentoxide $\left(\mathrm{Sb}_{2} \mathrm{O}_{5}\right)$, and superfine amorphous ferric oxide $\left(\mathrm{Fe}_{2} \mathrm{O}_{3}\right)$, on sediment dwelling invertebrates Chironomus tentans under controlled laboratory conditions. Percentage survival, enzyme activities, growth development, and DNA fragmentation parameters were studied as acute, biochemical, and physiological toxicities of NMs, respectively. Quantitation of catalase and peroxidase enzyme activity demonstrated that toxicant stress of the NMs increased enzyme activity in a concentration dependent fashion across all treatments. The percentage growth length of
\end{abstract}

† Corresponding author (N Musee), Fax: + 2712841 7738; Email: NMusee@csir.co.za or museen2001@yahoo.com. ${ }^{\#}$ These authors contributed equally to this research work. 
the test specimens exposed to different NMs was significantly reduced compared to the negative control while only five concentrations were not in the toxic range, namely; $\mathrm{Fe}_{2} \mathrm{O}_{3}(5 \mu \mathrm{g} / \mathrm{kg})$; silica fume $(5 \mu \mathrm{g} / \mathrm{kg}, 50 \mu \mathrm{g} / \mathrm{kg}) ; \mathrm{Sb}_{2} \mathrm{O}_{5}(5 \mu \mathrm{g} / \mathrm{kg})$ and calcined silica fume $(5 \mu \mathrm{g} / \mathrm{kg})$. Genotoxic stress assessed by use of DNA laddering showed complementary findings to the other ecotoxicological endpoints tested in this study the percentage survival and growth length inhibition.

Keywords: Nanomaterials, Chironomus tentans, bioassays, ecotoxicology, DNA damage.

\section{Introduction}

Nanotechnology is increasingly playing a leading role in society. It constitutes the use of materials and structures with nanoscale dimensions usually less than $100 \mathrm{~nm}$ (Roco, 2004; Royal Society and Royal Academy of Engineering Report, 2004; Roco, 2005). At present, manufactured nanomaterials (NMs) are used in a variety of commercial and industrial applications including fillers, biosensors, cosmetics, textiles, pharmaceuticals, environmental remediation, drug carriers, microelectronics, and catalysts (Masciangioli and Zhang, 2003; Shvendova and Castranova, 2003; Aitken, et al., 2006; Guzmán et al., 2006; Helland et al., 2007). NMs are highly attractive to a wide range of applications because of their unique physicochemical attributes (Rao and Cheetham, 2001); however, these same useful attributes could also prove deleterious and cause unexpected behaviour or responses in biological systems and the broader environment (Nel et al., 2006; Wiesner et al., 2006). 
Because of the wide and rapidly increasing use of commercial and industrial consumer products containing NMs, it is expected that the nanoscale materials will be released into the aquatic, terrestrial, and atmospheric environments (Wiesner et al., 2006; Nowack and Bucheli, 2007). Yet, despite the increased exposure of NMs to organisms in different environmental systems, the risks associated with nanoscale materials remain largely unknown (Borm et al., 2006a; Borm et al., 2006b).

Sediments are the ultimate repository of anthropogenic contaminants entering into water resources (Batley and Maher, 2001) - and likely final sink of NMs as they are generally insoluble in water. However, ecotoxicological studies on the effects of NMs on soil invertebrates are limited (Scott-Fordsmand et al., 2008), unlike the large and rapidly-growing scientific literature on nanotoxicity studies on mammals (Oberdörster et al., 1995; Dick et al., 2003; Donaldson and Golyansya, 2004; Lam et al., 2004; Oberdorster et al., 2005; Maynard et al., 2005; Lam et al., 2006) and aquatic organisms (Fortner et al., 2006; Lovern and Klape, 2006; Moore, 2006; Wang et al., 2006; Smith et al., 2007; Wang et al., 2008). Therefore, for a more holistic understanding of the fate and behaviour of NMs in the environment, studies on the effects of nanoscale materials on sediment-dwelling organisms are crucial for long-term safe and responsible development of nanotechnologies. For instance, the upper sediment layers of water bodies are an essential habitat for aquatic communities because the life cycle stages of most invertebrate stream-dwelling organisms are associated with this zone. Normally, sediment-dwelling organisms are exposed to contaminants from three sources, namely: interstitial water, sediment particles, and overlying water. In addition, benthic invertebrates often selectively consume different particle sizes or sediment particles containing high organic carbon content as well as elevated chemical concentrations 
(Harkey et al., 1994). This makes ecotoxicological studies of NMs in invertebrates crucially important because invertebrates constitute $95-97 \%$ of all known animal species.

In this study, the benthic invertebrate Chironomus tentans - a chironomid midge larva - was used as a test organism because of their widespread distribution and strong influence on the aquatic sediment environment through processes such as bioirrigation, bioturbation, sediment re-suspension, ingestion, digestion, excretion and secretion (Walshe, 1947; Aller and Aller, 1998). Because C. tentans constructs tubes from sediment particles, and ingests sediment particles, it is highly likely that these sediment feeders may accumulate high concentrations of contaminants in their bodies, including chemicals with nanoscale properties. However, the present knowledge concerning the ecotoxicological effects of NMs in benthic fauna is scanty and therefore needs to be studied and fully documented. The chemistry of most NMs makes them likely to be readily adsorbed onto the sediment particles, suggesting that chironomid species are likely to be exposed to NMs because these organisms ingest sediment particles. In addition, the study seeks to establish lethal and sub-lethal effects of the selected NMs on the chironomid larva $C$. tentans; and whether or not simple toxicity tests and bioassays can elucidate their effects on sediment-dwelling organisms.

The NMs tested in our study have considerable potential for exposure and persistence in ecological systems because they are not biodegradable. The seven NMs used in this study were precipitated silica (a silica grade widely used as a reinforcing filler in rubber compounds); silica fume and calcined silica fume (a by-product of silicon smelters and used in concrete); $\alpha$-alumina; $\gamma$-alumina; colloidal antimony pentoxide $\left(\mathrm{Sb}_{2} \mathrm{O}_{5}\right)$ (used as 
a colourless flame retardant in polymer films); and superfine amorphous ferric oxide $\left(\mathrm{Fe}_{2} \mathrm{O}_{3}\right)$, used as a catalyst or an ingredient in foods, drugs, and cosmetics. The NMs were chosen because they are either present in high-volume commercial and industrial uses, or constitute part of the by-products of industrial processes, or they are part of waste streams from industrial processes, which would considerably increase their exposure to diverse ecological systems.

\section{Materials and methods}

\subsection{Nanomaterials characterization}

Before the initiation of the toxicity and growth inhibition experiments, each NM was characterized to provide a basis for understanding their observed toxic effects. The NMs were characterized using a range of instrumental techniques. Physicochemical properties that were determined included: zeta potential, particle size, shape, density, solubility, surface area, and morphology. The X-ray powder diffraction (XRD, a Phillips PW 1830) generator was used to determine whether the compounds were in crystalline or amorphous forms. The morphology and size estimation of nanopowders were assessed in a JEOL JSM 1560 LV scanning electron microscope (SEM) (Jeol, Peabody, MA) under low magnification. Elemental composition was determined using energy dispersive X-ray fluorescence (XRF) analysis. Particle size and size

distributions were determined on a Malvern Zetasizer 3000 HSA (Malvern Instruments). Braunner, Emmett, and Teller (BET) surface areas were measured on a Micromeritics Flowsorb II 2300 instrument. 


\subsection{Sediment characterization and spiking}

The sediment used in all tests had a relative dry weight of $50 \%$ acid washed sand and $20 \%$ kaolin clay (BDH Chemicals Ltd, Poole, England, supplied both products). Physical characterization of the sediment entailed analysing the grain size with mean size of $0.25 \mathrm{~mm}$ (Plumb, 1981), and had total organic carbon of $0.01 \%$ (TOC) (ASTM, 1985, modified for sediment), however, the effect of the organic matter among other abiotic factors were not investigated in this study. In future studies, consideration on the environmental factors (e.g. $\mathrm{pH}$, organic matter, temperature, ionic charge, etc) will be taken into account to elucidate how they influence the observed toxicological effects of the $C$. tentans. The experiments were conducted in sediment samples that had been spiked with a panel of seven different NMs at four different concentrations, viz.; 5, 50, 500, and $5000 \mu \mathrm{g} / \mathrm{kg}$. Also, six negative control samples (sediment without NMs but containing $C$. tentans test specimens) were prepared and included in the analysis, following the same procedures.

The four different NMs concentrations were selected on the basis of a recent report by Markovic et al. (2007) which indicated that concentrations of most common nanoparticles (NPs) could be expected to be present in natural waters in the range 1 to $10 \mu \mathrm{g} / \mathrm{l}$ and total NP concentrations may approach $100 \mu \mathrm{g} / \mathrm{l}$, while values in sediment may be much higher. Hence, Klaine et al. (2008) suggested that sediments, and therefore benthic, organisms are expected to be the main sinks and receptors of NPs in surface waters, since metals, for example, tend to sorb to small colloids that aggregate and settle out from the water column to the sediments (Sigg et al., 1994). 
From a practical point of view, the NMs are expected to re-distribute between the water- and sediment-phases after release into water bodies. However, due to lack of metrology to measure NMs in the sediment compartment and particularly discriminate them against nanoparticles from natural sources, it was impossible to measure the ratio of NMs distribution between the water- and sediment-phase. However, this limitation is expected to be addressed in the coming years as new methods are currently being developed to readily provide real-time measurements distribution of NMs in soils and sediment - taking into account the background nanoparticles existing naturally in the environment (Maynard et al., 2006). In addition, the methods which are available to analyse the presence of inorganic NMs levels are limited due to mechanical and chemical effects induced on the nanoscale materials because of their sensitivity to any slight changes. Therefore, this challenge remains given the lack of analytical techniques which are non-evasive.

Analytical confirmation of the concentrations of the tested NMs in the sediment and overlying water column after the 10 day $C$. tentans test was not attempted in this study, because of the difficulties measuring NPs against a high background of natural colloids of the sediments (Klaine et al., 2008). Although preliminary work using a technique called flow field-flow fractionation coupled to an inductively coupled plasma mass spectrometer has the potential to provide concentrations, only preliminary data are available and further research is required (Klaine et al., 2008). However, in future experiments it would be advisable to measure the actual sediment concentrations of tested NMs when the appropriate analytical techniques are available. Considering the above, it is likely that the sediment concentrations of the different tested NMs decreased with time due to uptake and possibly metabolism by the test specimens. The 
possibility that the tested NMs desorbed from the sediment into the water column during the experiment has to be considered when evaluating the results in this study.

\subsection{Chironomus tentans whole sediment bioassay}

For the assessment of whole sediment toxicity, 10-day exposure tests of $C$. tentans were conducted. End-point measures were the survival percentage growth as a function of body length, No Observed Effect Concentrations (NOECs), Lowest Observed Effects Concentrations (LOECs) and changes in behaviour. Avoidance behaviour, which is the most immediate behavioural responses for a test species exposed to contaminated sediments were used by observing the relationship of the exposed $C$. tentans to the NMs spiked sediment in comparison to the non-spiked sediment (negative controls) within the first $48 \mathrm{~h}$ of exposure. Dwelling behaviour (i.e. test organisms entering the sediment) was used as measurement of avoidance behaviour. The toxicity tests and controls were measured in triplicate. The sediment volume for each test was $200 \mathrm{~g} / \mathrm{dry}$ weight and $175 \mathrm{ml}$ of overlying moderately hard EPA water containing $4 \mathrm{mg} / \mathrm{l} \mathrm{KCl} ; 60$ $\mathrm{mg} / \mathrm{l} \mathrm{MgSO}_{4} ; 96 \mathrm{mg} / \mathrm{l} \mathrm{NaHCO}_{3}$ and $\mathrm{CaSO}_{4} 2 \mathrm{H}_{2} \mathrm{O}$. The $\mathrm{pH}$ of the water was 7.3 and alkalinity (64 mg/l CaCO3) (Oberholster et al., 2005). Replicate sediment samples were spiked with four different NM concentrations (see section 2.2), and thereafter thoroughly mixed manually to ensure the homogeneity of the sample, particularly to avoid inconsistencies of the data for ecotoxicological analysis.

In this study, NMs were directly mixed with the sediments, excluding the inert carrier powder (with particle size closer to those of the NMs). The use of inert powders and dispersants to improve mixing and dispersion of NMs in media is not recommended as 
it affects the final results of ecotoxicity studies (Handy et al., 2008). In addition, overlying water was added to the test chambers three days (72 hours) before test initiation to allow the system to equilibrate in accordance to the USEPA (2000) guidelines. Then, second-to-third instar larvae were introduced into each of the test chambers containing sediment samples that had been spiked with four different concentrations for each NM type after the 72 hours of equilibration of the sediment. Ten second-to-third instar larvae were added per test chamber under a 16:8 hour light dark photoperiod at approximately temperature of $21 \pm 1^{\circ} \mathrm{C}$. The larval instar size was determined using head capsule size (McCauley, 1974). The overlying water in each of the test containers was renewed manually, with two volume replacements per day (USEPA, 2000).

The following water quality parameters, namely: $\mathrm{pH}$, alkalinity, conductivity, and ammonia were measured at test initiation and termination. However, both the temperature and dissolved oxygen (DO) of the overlaying water were monitored daily for 10 days. After 10 days, the mean survival of larvae exposed to the sediment at different concentrations for each NM type were obtained by gentle sieving, counted, and compared to the number of test specimens in the negative control. Also, the average body length of the test organisms at the initiation and termination times was compared. Alive Chironomids larvae were then placed individually in Eppendorf tubes, snap frozen in liquid nitrogen, and stored at $-80^{\circ} \mathrm{C}$ before enzyme and DNA fragmentation activity were conducted.

\subsection{Sublethal test}

\subsubsection{DNA strand breakage as indicator of genotoxicity in Chironomus $\underline{\text { tentans }}$}


DNA strand breakage was determined using the modified method of Cotter and Martin (1996). The C. tentans test specimens were isolated from the sediment after 10 days of exposure under different concentrations of each NM type. DNA strand breakage in $C$. tentans test specimens was assessed at four different concentrations for each NM type. This was to determine the lowest concentration per given material that causes observable genotoxicity effects. The tissue from each test specimen was macerated in liquid nitrogen before the DNA was extracted using the DNA apoptotic kit (Roche, Molecular Research Center, Inc., USA). Equal concentrations of the DNA from the test organisms after exposure to spiked sediment under different concentrations per NM type were loaded into the wells of a horizontal slab gel containing $1 \%$ agarose (Techcomp Ltd.), and were dissolved in 1x TAE buffer (Tris-acetate-EDTA buffer (pH 7.5)) containing Goldview. The generated fragments were separated at $85 \mathrm{Mv}$ for $1 \mathrm{~h}$, visualized under UV-light and then photographed.

\subsubsection{Antioxidant enzyme assays}

Only live Chironomid larvae were considered for enzyme assays. The Chironomid larvae were homogenized (10\% w/v) in $0.1 \mathrm{M}$ phosphate buffer $(\mathrm{pH} 7.5)$ and the crude homogenates were then centrifuged at $12,000 \mathrm{~g}$ for $10 \mathrm{~min}$. The resultant supernatant of the Chironomid larvae was used as the enzyme source to estimate the enzymatic activities (antioxidants). All the enzyme preparations were carried out at $4{ }^{\circ} \mathrm{C}$, and the total peroxidation activity in Chironomid larvae was determined using a guaiacol test (George, 1953). The rate of $\mathrm{H}_{2} \mathrm{O}_{2}$ disappearance (measured at $240 \mathrm{~nm}$ ) was used to quantify catalase activity in the Chironomid larvae (Beers and Sizer, 1952). The ratio 
between the enzyme activity to the protein content, expressed as optical density (O.D.)/ min per milligram protein, was calculated using the Bradford method (Bradford, 1976).

\subsection{Data analysis}

Comparisons within and among different concentrations of NMs for survival, growth length, and enzymatic activities were performed by one-way analysis of variance (ANOVA), followed by Sheffé's post hoc test. Differences were considered significant between the test categories at the 0.05 probability level. In addition, different concentrations of NMs were considered to be toxic if a given test endpoint - such as survival or growth length - was statistically different from those of test organisms $(\mathrm{p}<$ 0.05), and at least $20 \%$ lower than the mean test organism response in the negative control sample (Thursby et al. 1997).

\section{Results}

\subsection{Water quality}

The water quality parameters measured during the experiment remained similar across different treatments in terms of NMs concentrations ( $\mathrm{pH} 7.2-7.6$, temperature $19.7-$ $22.3{ }^{\circ} \mathrm{C}$, conductivity $243-312 \mu \mathrm{S} / \mathrm{cm}$, and dissolved oxygen $85-100 \%$ air-saturated volume).

\subsection{Nanomaterials properties}

Because the toxicological and environmental effects of NMs are a function of their physicochemical properties (Batley and Maher, 2001; Oberdorster et al., 2005; Nel et 
al., 2006; Powers et al. 2006; Warheit et al., 2007a; Warheit et al., 2007b; Handy et al., 2008) each material in this study was characterized using several techniques (see section 2.1). The reasons for this were two-fold. The observed toxicity and behavioral effects on the Chironomid larvae were likely to be due to multiple factors such as surface area, zeta potential, morphology, solubility, and size. Secondly, no single technique has the capability to determine all the physicochemical properties of a given NM. The qualitative and quantitative results of SEM, XRD, BET, etc., are presented in Table 1. SEM confirmed the presence of nanoscale structures of the test materials. For instance, Fig. 1 shows the morphology of three silica NMs. The observed differences in size, morphology, and shape of the silica NMs can be attributed to the method of producing silica fume, calcined silica fume, and the precipitated silica.
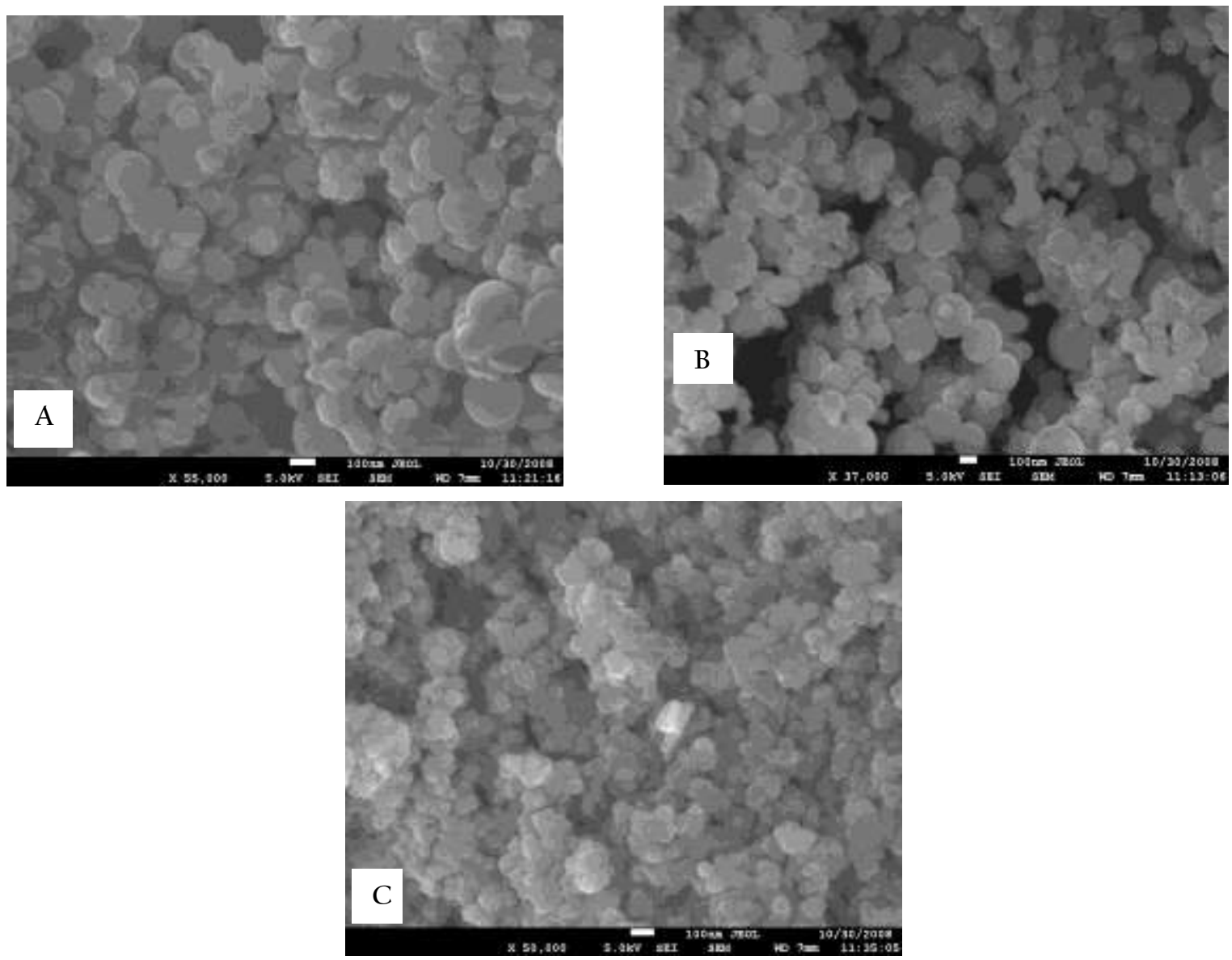

Fig. 1. SEM images of three silica NMs with different average particle sizes. (A) Silica fume (100-400) $\mathrm{nm}$; (B) Calcined silica fume (50-300) nm; and (C) Precipitated silica (20-100) nm. 
Table 1

The physicochemical properties of the test NMs, and summary of ranking essays outputs

\begin{tabular}{|c|c|c|c|c|c|c|c|c|}
\hline Test & Property/units & $\mathrm{Fe}_{2} \mathrm{O}_{3}$ & $\begin{array}{l}\text { Silica Fume } \\
\left(\mathrm{SiO}_{2}\right)\end{array}$ & $\begin{array}{l}\text { Calcined silica fume } \\
\left(\mathrm{SiO}_{2}\right)\end{array}$ & $\begin{array}{l}\text { Precipitated } \\
\text { silica }\left(\mathrm{SiO}_{2}\right)\end{array}$ & $\mathrm{Sb}_{2} \mathrm{O}_{5}$ & $\alpha$-alumina & $\gamma$-alumina \\
\hline Zeta potential & $\mathrm{mV}$ & -18.3 & -21.1 & -14.6 & -1.76 & -23.4 & 19.7 & -18.7 \\
\hline \multirow[t]{2}{*}{ BET } & $\begin{array}{l}\text { Surface area } \\
\left(\mathrm{m}^{2} / \mathrm{g}\right)\end{array}$ & 235 & 24 & 17 & 157 & 3 & 13 & 72 \\
\hline & Density $\left(\mathrm{g} / \mathrm{cm}^{3}\right)$ & 5.2 & 2.10 & $2.1-2.4$ & 2.0 & 4.07 & 3.6 & 3.97 \\
\hline $\begin{array}{l}\text { Surface/volume } \\
\text { ratio }\end{array}$ & $\mathrm{m}^{2} / \mathrm{mm}^{3}$ & 1274 & 50 & 41 & 314 & 12 & 47 & 286 \\
\hline XRD & Morphology & Crystalline & Amorphous & Amorphous & Amorphous & Crystalline & Amorphous & Crystalline \\
\hline SEM & Particle shape & spherical & spherical & spherical & spherical & $\begin{array}{l}\text { Mixture ( spheres, } \\
\text { irregular) }\end{array}$ & spherical & spherical \\
\hline Zetasizer & Size $(n m)$ & $50-150$ & $100-400$ & $50-300$ & $20-100$ & $5000-15000$ & $20-50$ & $80-400$ \\
\hline Solubility & Degree & Insoluble & Insoluble & Insoluble & Insoluble & Insoluble & Insoluble & $\begin{array}{l}\text { Slightly } \\
\text { Soluble }\end{array}$ \\
\hline $\begin{array}{l}\text { Degree of } \\
\text { dispersion }\end{array}$ & No units & Mono & Poly & Poly & Mono & Poly & Mono & Poly \\
\hline \multirow{4}{*}{$\begin{array}{l}\text { Ranking of the } \\
\text { toxic effects }\end{array}$} & Growth inhibition & 4 & 7 & 6 & 3 & 5 & 2 & 1 \\
\hline & DNA damage & 4 & ND & ND & 3 & 5 & 2 & 1 \\
\hline & Survival levels & 5 & 7 & 6 & 3 & 4 & 2 & 1 \\
\hline & $\begin{array}{l}\text { Enzymatic } \\
\text { activities }\end{array}$ & 4 & 7 & 6 & 3 & 5 & 1 & 2 \\
\hline
\end{tabular}




\subsection{Chironomid survival and growth length}

Fig. 2 shows the surviving percentages of organisms under each treatment. The results show that only five concentrations of different NMs spiked into the sediment were not toxic to the test organisms when compared to the negative control tests results. The non-toxic concentrations (NOECs) were observed for the following NM's namely: $\mathrm{Fe}_{2} \mathrm{O}_{3}(5 \mu \mathrm{g} / \mathrm{kg}) ;$ Silica Fume $(50 \mu \mathrm{g} / \mathrm{kg}, 5 \mu \mathrm{g} / \mathrm{kg}) ; \mathrm{Sb}_{2} \mathrm{O}_{5}(5 \mu \mathrm{g} / \mathrm{kg})$ and calcined silica $(5 \mu \mathrm{g} / \mathrm{kg})$. The lowest percentage of surviving test organisms $(13 \% ; \mathrm{n}=30)$ differed significantly $(p \leq 0.05)$ between the negative control and test specimens exposed to with the concentration of $5000 \mu \mathrm{g} / \mathrm{kg}$ of $\gamma$-alumina. Larvae in the $5000 \mu \mathrm{g} / \mathrm{kg}$

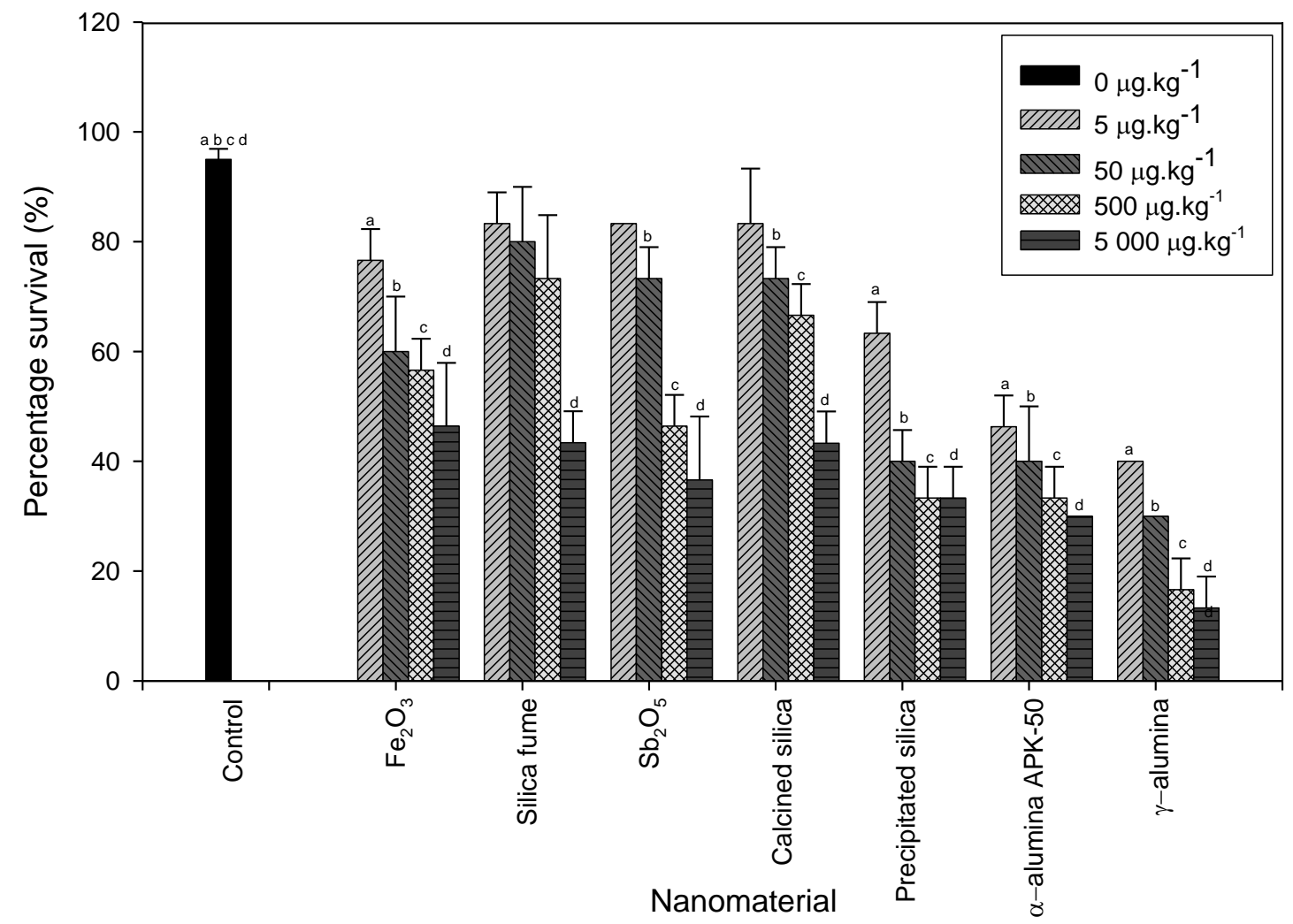

Fig. 2. Percentage survival of Chironomus tentans larvae following a 10-day exposure period to spiked sediment with different concentrations of NMs (mean of 3 replicates \pm SD error bars). Similar alphabetic letters indicate significant differences between the respective treatment and negative control $(p<0.05)$. 
treatment range of $\gamma$-alumina, $\alpha$-alumina, and $\mathrm{Sb}_{2} \mathrm{O}_{5}$ tended to avoid the spiked sediment within the first 48 hours of the experiment.

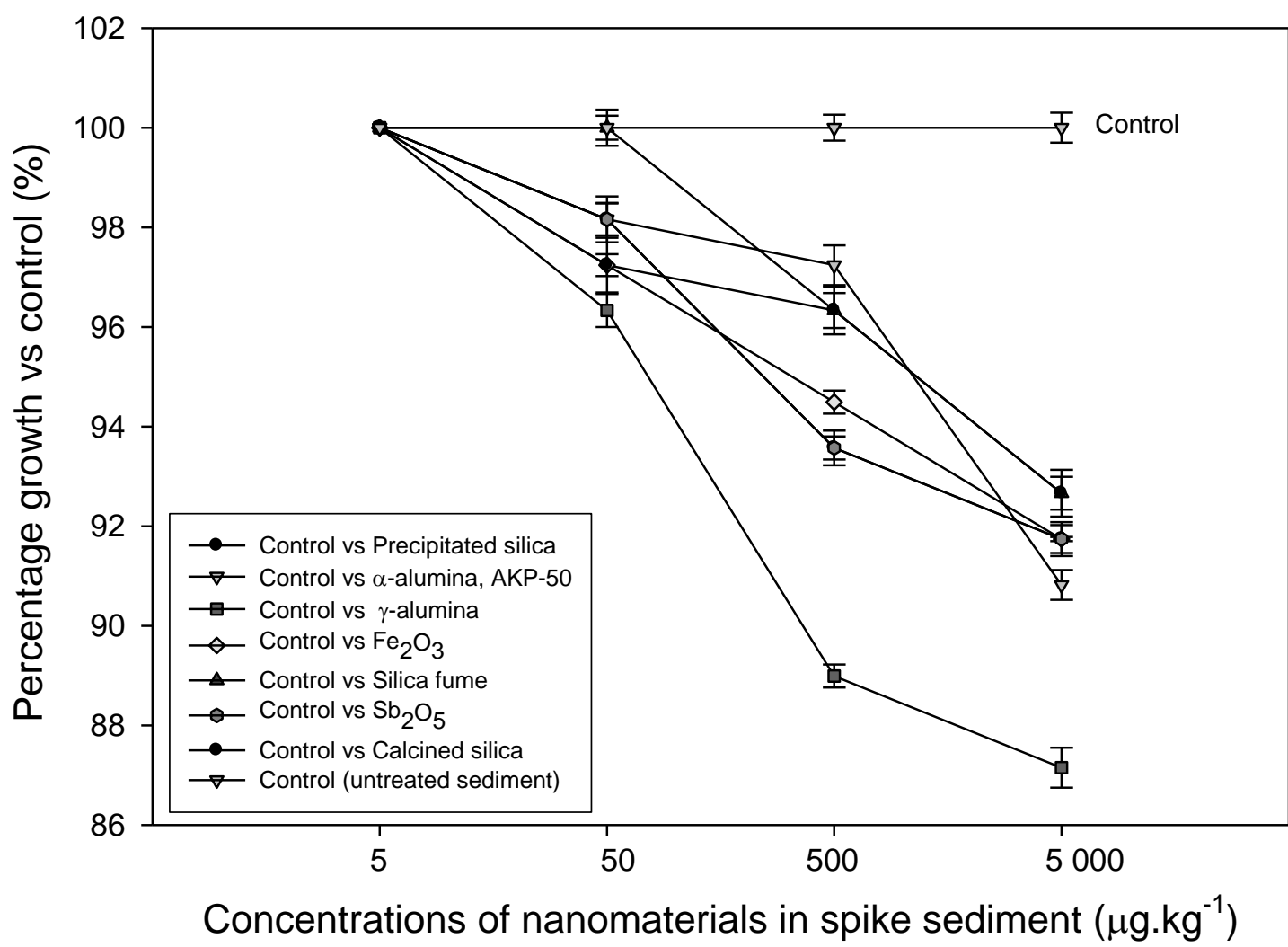

Fig. 3. Effects of different concentrations of NMs on growth (\%) in three instar larvae of Chironomus tentans expressed as a percentage of the corresponding control value (mean of 3 replicates \pm SD error bars).

The growth length of test organisms declined with increasing concentrations of different NMs in all treatments over the 10 days exposure period (Fig. 3) with significant $(p \leq 0.05)$ effects observed at $5000 \mu \mathrm{g} / \mathrm{kg}$ concentration between the negative controls and growth length of test organisms exposed to different NMs.. At the lowest concentration (NOECs) of $5 \mu \mathrm{g} / \mathrm{kg}$ no growth inhibition was observed with respect to the control for any given NM. The highest inhibition (\% reduction) of growth length of test organisms compared to the control organisms over the test period was observed at $5000 \mu \mathrm{g} / \mathrm{kg} \gamma$-alumina (Fig. 3). Also, there was a relationship between the 
highest inhibition $(13 \% ; n=30)$ and the highest concentrations of different NMs (5 000 $\mu \mathrm{g} / \mathrm{kg})$ in the spiked sediment.

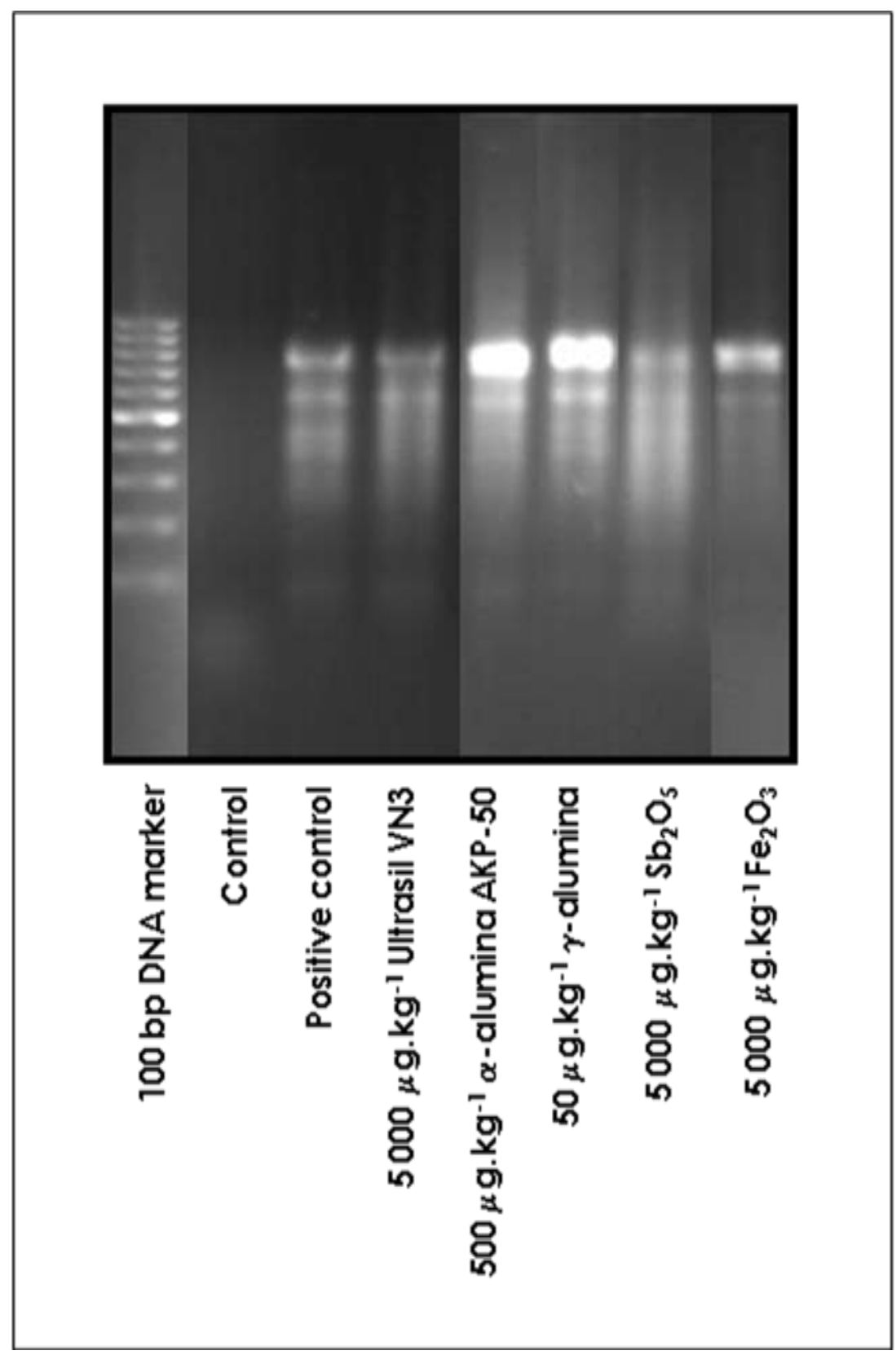

Fig. 4. Observation of DNA ladder bands by agarose gel electrophoresis in Chironomus tentans larvae after a 10 day exposure to spiked sediment with different concentrations of nanomaterials. 


\subsection{DNA strand breakage as indicator of genotoxicity}

DNA ladder bands are an indicator of acute and chronic chemical stress, loss of cellular function and structure - and were observed at different concentrations of various NMs (Fig. 4). DNA cleavage which is an indicator of irreversible completion of apoptosis occurred in organisms exposed to $5000 \mu \mathrm{g} / \mathrm{kg}$ concentrations (LOECs) of precipitated silica, $\mathrm{Fe}_{2} \mathrm{O}_{3}$ and $\mathrm{Sb}_{2} \mathrm{O}_{5}$ NMs. For the case of $\gamma$-alumina and $\alpha$-alumina treatments, the inter-nucleosomal DNA ladder bands occurred at lower concentrations (LOECs) of 50 $\mu \mathrm{g} / \mathrm{kg}$ and $500 \mu \mathrm{g} / \mathrm{kg}$, respectively, in comparison to the rest of NMs used in this study. Equally important, the DNA findings closely correlated with those obtained for the survival end-point.

\subsection{Antioxidant enzymes activities}

The enzymatic activities in the Chironomid larvae exposed to precipitated silica; calcined silica fume; $\gamma$-alumina; $\mathrm{Sb}_{2} \mathrm{O}_{5} ; \alpha$-alumina, AKP-50; silica fume and $\mathrm{Fe}_{2} \mathrm{O}_{3}$ are shown in Fig. 5. The catalase enzyme activity increased across all treatments of precipitated silica; $\gamma$-alumina; $\mathrm{Sb}_{2} \mathrm{O}_{5} ; \alpha$-alumina, and $\mathrm{Fe}_{2} \mathrm{O}_{3}$ when compared to the control. The highest increase in catalase enzyme activity was observed in specimens exposed to $5000 \mu \mathrm{g} / \mathrm{kg}$ of $\gamma$-alumina and $\alpha$-alumina. The highest catalase activity (average 9 OD $\mathrm{mg}$ protein $\mathrm{min}^{-1}$ ) also differed significantly $(p \leq 0.05)$ with the specimens exposed to the highest concentration $(5000 \mu \mathrm{g} / \mathrm{kg})$ of $\gamma$-alumina and $\alpha$ alumina in comparison with the negative controls. In contrast, peroxidase activities decreased as the NMs concentrations increased, particularly when compared with the 


\section{Catalase activity}

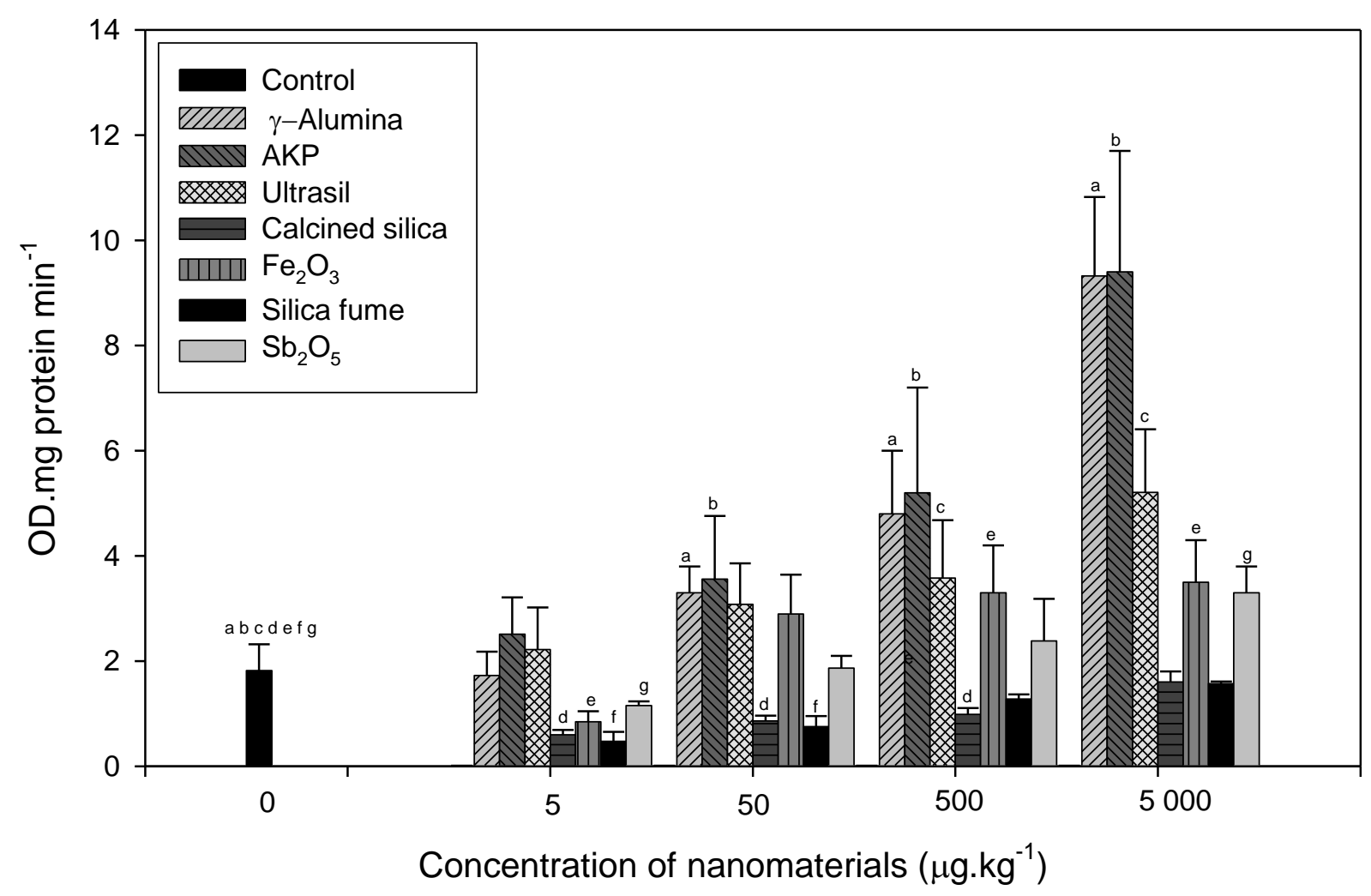

Fig. 5. Catalase activities (OD. $\mathrm{mg}$ protein $\mathrm{min}^{-1}$ ) in Chironomus tentans larvae after a 10-day exposure to spiked sediment with different concentrations of nanomaterials (mean of 3 replicates \pm SD error bars). Similar alphabetic letters indicate significant differences between the respective treatment and negative control $(p<0.05)$.

control. The lowest enzyme activity was observed in specimens exposed to sediment spiked with $5000 \mu \mathrm{g} / \mathrm{kg}$ of $\alpha$-alumina (Fig. 6). 


\section{Peroxidase activity}

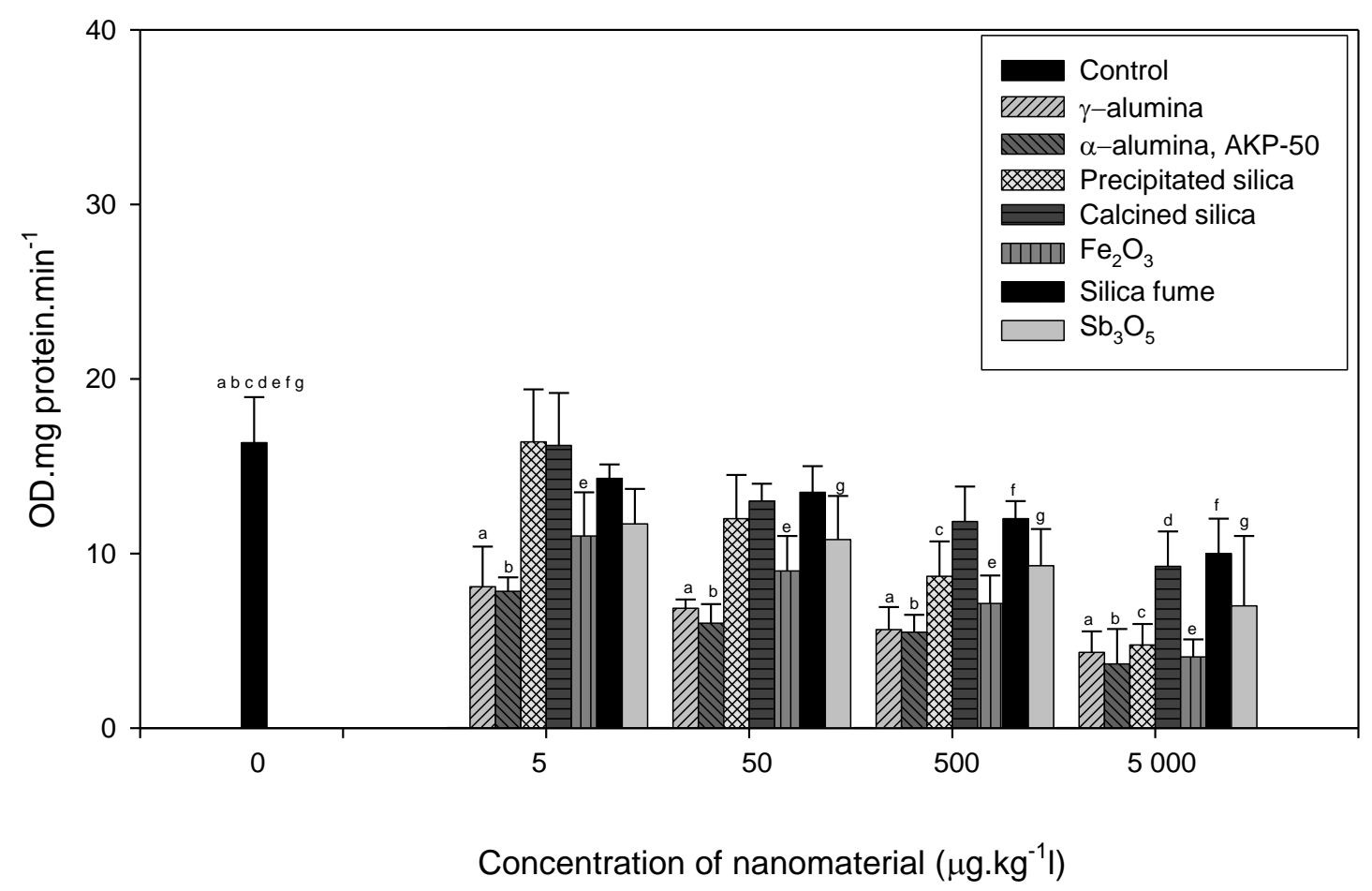

Fig. 6. Peroxidase activities (OD. $\mathrm{mg}$ protein $\mathrm{min}^{-1}$ ) in Chironomus tentans larvae after a 10-day exposure to spiked sediment with different concentrations of nanomaterials (mean of 3 replicates \pm SD error bars). Similar alphabetic letters indicate significant differences between the respective treatment and negative control $(p<0.05)$.

\section{Discussion}

In order to understand the impacts of NMs on sediment-dwelling organisms - $C$. tentans invertebrates were exposed to a panel of seven NMs.. Also, to illustrate whether different NMs composed of the same parent material may exhibit a possible variation in toxicity, we purposely selected three silica- and two alumina-based NMs in the panel of materials investigated in this study, as a function of their sources, methods of production, and differences in diverse physicochemical properties. 
In this study, four parameters were measured at different biological levels of organization and specific endpoints to elucidate the effects of NMs exposure on $2^{\text {nd }}$ and $3^{\text {rd }}$ instar Chironomid larvae. These comprised of: the physiological parameter (growth inhibition), enzymatic activities, survival levels, and DNA damage - and the observed effects in each case after exposure to different NMs were found to be concentrationdependent. Traditionally, biotoxicity tests using $C$. tentans have relied on numbers of organisms or percentage survival as an end-point (acute toxicity) rather than sub-lethal effects of toxic substances. However, the findings of Benoit and co-workers (Benoit et al., 1997) illustrated that the population- or community-level impacts of toxic substances are more likely to cause chronic or sub-lethal effects in the exposed organisms as opposed to the occurrence of mortality.

More recently, the growth of an organism has become a common sub-lethal end-point and biomarker for assessing the toxic effects of substances to aquatic life forms. In this study, we observed stress on organisms owing to the environmental contaminants in the form of NMs, causing growth inhibition in comparison to the control organisms. Similar effects were observed by Karouna-Renier and Zehr (1999) for macroscale chemical pollutants. The decrease in growth length as the concentration of NMs increased suggests the alteration of this parameter due to advanced progression of toxic effects of the NMs on the test organisms. Reduction in growth rate caused the organisms to mature at smaller sizes, and minimizes their ability to reproduce. Similar results were recently reported by Lovern and co-workers (Lovern et al., 2007) after exposing Daphnia magna to titanium dioxide and carbon-based NMs (fullerenes and and $\left.\mathrm{C}_{60} \mathrm{HxC}_{70} \mathrm{Hx}\right)$. 
In addition, the toxic effects were likely to have caused a decrease in energy, and may have lowered the reproduction of the organisms. Moreover, the availability of cellular energy (ATP levels) also acts as a biochemical checkpoint influencing the switch between apoptotic and necrotic patterns of cell death (Sweet et al., 1999). The amount of cellular energy acts both as a metabolic parameter and a regulator of toxicantinduced apoptotic (lower dose of toxic substances, lower toxic stress, energy intact) and necrotic (higher dose of toxic substances, higher toxic stress, low energy) cell death (Sweet et al., 1999).

The avoidance response which is the final outcome of a sequence of neurophysiological events involving sensory neurons which elicit behavioural changes of the $C$. tentans larvae within the first 48 hours in the spiked sediment samples containing $1 \mathrm{~g} / 1$ of $\gamma$ alumina, $\alpha$-alumina, and $\mathrm{Sb}_{2} \mathrm{O}_{5}$ illustrated the possibility of increased mortality due to predation in a natural aquatic environment. This implies that $C$. tentans larvae are likely to become more visible to predators because of the presence of NMs - particularly those which are highly toxic. Such an eventuality is likely to cause a dramatic decline in larval populations due to predation, and consequently, this would fundamentally alter the population structure of the benthic community. Nonetheless, previous studies have shown that Chironomus has an efficient biochemical defence mechanism, which may contribute to its ability to tolerate varied environmental stresses (Lee and Choi, 2007).

For instance, different molecular and biochemical parameters such as heat shock protein and hemoglobin gene expression, measured in earlier studies, have showed that these organisms are highly sensitive to environmental pollutants (Karouna-Reiner and Zehr, 1999; Choi et al., 2000; Choi et al., 2001; Lee et al., 2006). Chironomus exposure 
to environmental contaminants can generate excessive free radicals leading to the accumulation of $\mathrm{O}_{2}^{-}$and $\mathrm{H}_{2} \mathrm{O}_{2}$ (Choi et al., 2000). The generation of reactive oxygen species (ROS) further leads to oxidative destruction of cell components, oxidative DNA damage as well as lipid peroxidation - which then causes inactivation of enzymes, mutations and ultimately cell death (Davis, 1987; Elia et al., 2003). In this study, consistent correlations between the increase in catalase enzyme activity with a corresponding increase in NMs concentrations was observed (Fig. 5). These findings suggest possible stimulation of antioxidant defence mechanisms as a consequence of excessive generation of superoxide radicals triggered by different NMs (Fig. 4).

An increase in catalase activity in concentration-dependent versions of different NMs, specifically $\gamma$-alumina, $\alpha$-alumina, precipitated silica, $\mathrm{Sb}_{2} \mathrm{O}_{5}$ and $\mathrm{Fe}_{2} \mathrm{O}_{3}$, could be due to activation caused by superoxide radicals. Alternatively, this could be due to increases in the rate of the reaction because of excessive production of hydrogen peroxide $\left(\mathrm{H}_{2} \mathrm{O}_{2}\right)$. The catalase enzyme functions rapidly and dissociates $\mathrm{H}_{2} \mathrm{O}_{2}$ into water and oxygen. Therefore, any significant change in antioxidant levels alter peroxidation as their production above normal levels renders it non-feasible to quench the excess free radicals generated (Vutukuru et al., 2006). An increase in catalase enzyme activity at concentrations exceeding $50 \mu \mathrm{g} / \mathrm{kg}$ for $\gamma$-alumina, $\alpha$-alumina, precipitated silica, $\mathrm{Sb}_{2} \mathrm{O}_{5}$ and $\mathrm{Fe}_{2} \mathrm{O}_{3}$ occurred concomitantly with peroxidase activation within the test specimens, which could reflect adverse effects at high concentrations of NMs.

These findings concur with earlier observations of Lee and Choi (2007) who reported an increase in catalase levels and activation of peroxidase enzyme activity after exposure of Chironomus riparius to high concentrations of ethynyl estradiol - a well- 
known endocrine-disrupting chemical. The data would appear to indicate that there are similarities in the antioxidant defense responses to toxic substances between these Chironomus species and that the mechanisms causing toxicity because of nanoscale properties were probably similar as those of macroscale compounds. Nonetheless, more studies are required to clarify if the mechanisms causing toxicity are similar for both the macroscale and nanoscale materials.

Peroxidasic activity is a well-known property of hemoglobin (Everse et al., 1990). Choi and co-workers (Choi et al., 2000) showed for normoxic conditions that $C$. riparius hemolymph contains approximately $90 \%$ of the total peroxidase activity and that the hemoglobin levels and peroxidase activity are positively correlated. Therefore, the changes in peroxidase activity caused by different concentrations of diverse NMs may be hemoglobin dependent (Choi et al., 2000). However, this aspect will be further investigated in our future studies in an endeavor to establish the underlying mechanisms, taking into account the unique physicochemical properties of NMs that underpin their observed toxicity effects.

The discriminating power of DNA strand breakage as a genotoxicity parameter - as used in this study in comparison to other ecotoxicological endpoints such as \% survival and growth length inhibition - can be accounted for by the genotoxic signal resulting from both DNA damage and repair capabilities of Chironomid larvae. Genotoxic effects as measured through the DNA strand breakage are of significant interest in ecotoxicology because they can potentially cause long-term inheritable disorders, thereby affecting the genetic population structure in the aquatic environment (Depledge, 1996). Therefore, the responses at molecular level serve as an indicator of 
both exposure and toxic effects of NMs and underlines the noticeable changes in a given population or community structure (Stegeman et al., 2001). In this study, DNA strand breakage findings are complementary to the other ecotoxicological endpoints that were investigated, namely: percentage survival and growth length inhibition, and proof a useful tool in the suite of biomarkers used to analyze the impacts NMs - both engineered particles and those that are generated accidentally during industrial processes.

Table 1 summarizes the physicochemical properties and the ranking of toxic effects on the $C$. tentans test larvae. Results show that while each material had nanoscale attributes, the observed toxic effects were substantially different even for materials derived from the same bulk parent material (e.g. for silica- and aluminium-based NMs). The results suggest that this could be due to the physicochemical properties of a given $\mathrm{NM}$, particularly taking into account some of the test materials have the same chemical structure (e.g. silica fume, calcined silica fume, and precipitated silica). Secondly, it points to the danger that NMs of the same material (class), for example silicas or aluminas, will exhibit different toxic effects to the same organism(s) in the ecosystems. This clearly implies that each NM is unique, has unique properties and effects, and the risk assessment for each should be evaluated on a case-by-case basis, and the possibility of generalizing the results may be dangerously misleading.

The results of the organisms' survival, enzyme activities, growth development, and DNA fragmentation parameters indicate that the toxicity of the NMs used in this study (to $C$. tentans) ranks as follows: $\gamma$-alumina $>\alpha$-alumina $>$ precipitated silica $>\mathrm{Fe}_{2} \mathrm{O}_{3}$ $>\mathrm{Sb}_{2} \mathrm{O}_{5}$; calcined silica fume $>$ silica fume. To account for the toxicity differences, we 
attempted to correlate the physicochemical properties of the NMs with the observed effects. The four most toxic NMs, namely; $\gamma$-alumina, $\alpha$-alumina, and precipitated silica> $\mathrm{Fe}_{2} \mathrm{O}_{3}$ were characterised by high surface volume ratio (except $\alpha$-alumina), high degree of monolithic degree of dispersion (except $\gamma$-alumina), and the average sizerange for all NMs was under $100 \mathrm{~nm}$.

On the other hand, the rest of the NMs that were tested and which elicited lower toxic effects, were larger in size than the former. This suggests that the NMs agglomerated or were poly-dispersed, resulting in low surface area to volume ratios. This shows that the toxicity of NMs is unlikely to be as result of a single physicochemical property, but a combination; an aspect that merits to be addressed carefully through further research. Additionally, because this study was conducted using washed sand, this considerably reduced the possible influence of abiotic-factor effects due to total suspended solids, dissolved organic matter, absence of polysaccharides and saccharides, ionic strengths, etc. Although the results from this study show that the NMs under investigation are potentially toxic, further experiments are underway to confirm the findings.

The physicochemical properties of alumina-based NMs may account for their highly toxic effects. $\gamma$-alumina NMs are slightly soluble in water and this mediated the changes in the microenvironment of $C$. tentans through increased generation of ions that led to the formation of extracellular ROS. This in turn, caused the observed cell damage. On the other hand, the $\alpha$-alumina toxicity is potentially due to its high positive surface charge, because it has a lower surface area to volume ratio in comparison to precipitated silica and $\mathrm{Fe}_{2} \mathrm{O}_{3}$. The net positive surface induced superoxide-anion production, which leads to lipid peroxidation, and the observed cytotoxicity (Nel et al., 
2006). It has also been shown that the net positive charge on the nanoparticle prolongs the NM residence time in an organism's blood stream by hindering their opsonization and clearance by macrophages (Owens and Peppas, 2006). The hydrophilic surface also creates a steric repulsion between individual nanoparticles, which delays their agglomeration. We postulate that this property may be responsible for the enhanced nanoparticle toxicity observed in this study. Finally, the three silica-based NMs showed different toxicological effects though they were derived from the same bulk-parent material. The difference in toxicological effects can be accounted by examining the physicochemical properties where though all were similar save zeta potential, surface area, and degree of dispersion rendered the precipitated silica to more toxic to the $C$. tentans than for the case of calcined silica fume and silica fume. For instance, the precipitated silica had a higher zeta potential (close to zero), surface area (about six times that of silica fume and about nine times that of calcined silica fume) and monodispersed (making the particles to exhibit enhanced interactions with the $C$. tentans).

\section{Conclusions}

Currently, there are no factual data on concentrations of NMs in the environment, and certainly none on their physicochemical forms or distribution. Much of the available information regarding the behaviour of NPs in the environment and their interaction with biological life forms are generated through model NPs like black carbon, fullerenes and carbon nanotubes. Sediments which form an important part of the aquatic system act as a sink for, and a source of, anthropogenic contamination in water resources. In this study we demonstrated that the measured stress indicators ranging from the molecular to the organism level was NM concentration-dependent. From the 
data generated it was evident that certain threshold concentrations of the tested NM's in the spiked sediment have the potential to negatively affect benthic organisms survival and behaviour; and alter benthic ecosystems which form an important part of the aquatic environment and the food web. However, further studies are needed to determine if the tested NM's within the spiked sediment diffuse into the overlying water and vice versa, and if these actions are dependent on a concentration gradient and/or the sediment porosity.

\section{Acknowledgements}

The Parliamentary Grant funding support (NO. JNPPG03) from the CSIR (NM, PJO, PJA) as well as the research funding from the University of Pretoria (WWF), University of Limpopo (PKC), University of Stellenbosch (AMB) are acknowledged. The authors express their sincere gratitude to the three unknown referees for critically reviewing the manuscript and suggesting useful changes.

\section{References}

Aitken, R.J., Chaudhry, M.Q., Boxall, A.B.A., Hull, M., 2006. Manufacture and use of nanomaterials: Current status in the UK and global trends. Occup. Med. (Lond). $56,300-306$.

Aller, R.C., Aller, J.Y., 1998. The effects of biogenic irrigation intensity and solute exchange on diagenetic reaction rates in marine sediments. J. Mar. Res. 56, 905936.

ASTM D3668-78, 1985. Standard Test Method for Bearing Ratio of Laboratory Compacted Soil-Lime Mixtures, American Society for Testing and Materials. 
Batley, G.E., Maher, W.A., 2001. The development and application of ANZECC and ARMCANZ sediment quality guidelines. Aust. J. Ecotox. 7, 81-92.

Beers, J.R., Sizer, I.W., 1952. A spectrophotometric method for measuring the breakdown of hydrogen peroxide. J. Biol. Chem. 195, 133-140.

Benoit, D.A., Sibley, P.K., Jeunemann, J.L., Ankley, G.T. 1997. Chironomus tentans life-cycle test: Design and evaluation for use in assessing toxicity of contaminated sediments. Environ. Toxicol. Chem. 16, 1165-1176.

Borm, P.J.A.D., Robbins, D., Haubold, S., Kuhlbusch, T., Fissan, H., Donaldson, K., Schins, R., Stone, V., Kreyling, W., Lademann, J., Krutmann, J., Warheit, D., Oberdorster, E., 2006a. The potential risks of nanomaterials: a review carried out for ECETOC. Part. Fibre Toxicol. 3,11.

Borm, P.J.A.D., Klaessig, F.C., Landry, T.D., Moudgil, B., Pauluhn, J., Thomas, K., Trottier, R., Wood, S. 2006b. Research strategies for safety evaluation of nanomaterials, Part V: Role of dissolution in biological fate and effects of nanoscale particles. Toxicol. Sci. 90, 23-32.

Bradford, M.M., 1976. A rapid and sensitive method for the quantification of microgram quantities of protein utilising the principle of protein-dye binding. Anal. Biochem. 72, 248-254.

Choi, J., Roche, H., Caquet, T., 2000. Effects of physical (hypoxia, hyperoxia) andchemical (potassium dichromate, fenitrothion) stress on antioxidant enzyme activities in $C$. riparius $\mathrm{Mg}$ (Diptera, Chironomidae) larvae: potential biomarkers. Environ. Toxicol. Chem. 19, 495-500.

Choi, J., Roche, H., Caquet, T., 2001. Hypoxia, hyperoxia and exposure to potassium dichromate or fenitrothion alter the energy metabolism in Chironomus riparius Mg. (Diptera: Chironomidae) larvae. Comp. Biochem. Physiol. C130, 11-17. 
Cotter, T.G., Martin, S.J., 1996. Techniques in Apoptosis: A user's guide, London: Portland Press Ltd, pp. 331.

Davis, K.J.A., 1987. Protein damage and degradation by oxygen radicals. I. General aspects, J. Biol. Chem. 262, 9895-9901.

Depledge, M.H., 1996. Genetic ecotoxicology: an overview. J. Exp. Mar. Biol. Ecol. 200, 57-66.

Dick, C.A.J., Brown, D.M., Donaldson, K., Stone, V., 2003. The role of free radicals in the toxic and inflammatory effects of four different ultrafine particle types. Inhal. Toxicol. 15, 39-52.

Donaldson, K., Golyasnya, N., 2004. Cytogenetic and pathogenic effects of long and short amosite asbestos. J. Pathol. 177, 303-307.

Elia, C., Galarini, R., Taticchi, M.I., Dorr, A.J., Mantilacci, L., 2003. Antioxidant responses and bioaccumulation in Icttalurus melas under mercury exposure. Ecotoxicol. Environ. Saf. 55, 162-167.

Everse, J., Johnson, M.C., Marini, M.A. 1990. Peroxidative activities of hemoglobin and hemoglobin derivatives. Methods Enzymol. 186, 547-561.

Fortner, J.D., Lyon, D.Y., Sayes, C.M., Boyd, A.M., Falkner, J.C., Hotze, E.M., Alemany, L.B., Tao, Y.J., Guo, W., Ausman, K.D., Colvin, V.L., Hughes, J.B., 2005. $\mathrm{C}_{60}$ in water: Nanocrystal formation and microbial response. Environ. Sci. Technol. 39, 4307-4316.

George, P., 1953. Intermediate compound formation with peroxidase and strong oxidizing agents. J. Biol. Chem. 201, 413-426.

Guzmán, K.A.D., Taylor, M.A., Banfield, J.F., 2006. Environmental risks of nanotechnology: National Nanotechnology Initiative funding, 2000-2004. Environ. Sci. Technol. 40, 1401-1407. 
Handy, R.D.F., von der Kammer, F., Lead, J.R., Hassello“v, M., Owen, R., Crane, M., 2008. The ecotoxicology and chemistry of manufactured nanoparticles. Ecotox. 17, 287-314.

Harkey, G.A., Landrum, P.F., Klaine, S.J., 1994. Preliminary studies on the effects of feeding during whole sediment bioassays using Chironomus riparius larvae, Chemosphere 28, 597-606.

Helland, A., Wick, P., Koehler, A., Schmid, K., Som, C., 2007. Reviewing the environmental and human health knowledge base of carbon nanotubes. Environ. Health Perspect. 115, 1125-1131.

Karouna-Renier, N.K., Zehr, J.P., 1999. Ecological implications of molecular biomarkers assaying sub-lethal stress in the midge Chironomus tentans using heat shock protein 70 (HSP-70) expression. Hydrobiologia 401, 255-264.

Klaine, S.J., Alvarez, P.J.J., Batley, G.E., Fernandes, T.F., Handy, R.D., Lyon, D.Y., Mahendra, S., McLaughlin, M.J., Lead, J.R., 2008. Nanomaterials in the environment: behavior, fate, bioavailability, and effects. Environmental Toxicology and chemistry $27,1825-1851$.

Lam, C-W., James, J.T., McCluskey, R., Arepalli, S., Hunter, R.L., 2004. Pulmonary toxicity of single-wall carbon nanotubes in mice 7 and 90 days after intratracheal instillation. Toxicol. Sci. 77, 126-134.

Lam, C-W., James, J.T., McCluskey, R., Arepalli, S., Hunter, R.L., 2006. A review of carbon nanotube toxicity and assessment of potential occupational and environmental health risks. Crit. Revi. Toxicol. 36, 189-217.

Lee, S-M., Lee, S-B., Park, C-H., Choi, J., 2006. Expression of heat shock protein and hemoglobin genes in Chironomus tentans (Diptera, Chironomid) larvae exposed 
to various environmental pollutants: A potential biomarker of freshwater monitoring, Chemosphere 6, 1074-1081.

Lee, S-B., Choi, J., 2007. Effects of bisphenol A and ethynyl estradiol exposure on enzyme activities, growth and development in the four instar larvae of Chironomus riparius (Diptera, Chironomidae). Ecotoxicol. Environ. Saf. 68, 8490.

Lovern, S.B., Klape, R.D., 2006. Daphnia magna mortality when exposed to titanium nanoparticles and fullerene (C60) nanoparticles. Environ. Toxicol. Chem. 25, $1132-1137$

Lovern, L.B., Strickler, J.R., Klaper, R., 2007. Behavioral and physiological changes in Daphnia magna when exposed to nanoparticle suspensions (Titanium Dioxide, Nano- $\mathrm{C}_{60}$, and $\left.\mathrm{C}_{60} \mathrm{HxC}_{70} \mathrm{Hx}\right)$. Environ. Sci. Technol. 41, 4465-4470.

Masciangioli, T., Zhang, W-X., 2003. Environmental technologies at the nanoscale. Environ. Sci. Tech. 104A, 102-108.

Markovic, Z., Todorovic-Markovic, B., Kleut, D., Nikolic, N., Vranjes-Djuric, S., Misirkic, M., Vucicevic, L., Janjetovic, K., Isakovic, A., Harhaji, L., Babic-Stojic, B., Dramicanin, M., Trajkorvic, V., 2007. The mechanism of cell-damaging reactive oxygen generation by colloidal fullerenes. Biomaterials 28, 5437-5448.

Maynard, A.D., Kuempel, E.D., 2005. Airborne nanostructured particles and occupational health. J. Nanotechnol. Res. 7, 587-614.

Maynard, A.D., Aitken, R.J., Butz, T., Colvin, V., Ken Donaldson, K., Oberdörster,G., Philbert, M.A., Ryan, J., Seaton, J., Stone, V., Tinkle, S.S., Tran, L., Walker, N.J., Warheit, D.B., 2006. Safe handling of nanomaterials. Nature 444, 267-269. McCauley, V.J.E., 1974. Instar differentiation in larval Chironomidae (Diptera). Can. Entomol. 106, 179-200. 
Moore, M.N., 2006. Do nanoparticles present toxicological risks for the health of the aquatic environment? Environ. Int. 32, 967-976.

Nel, A., Xia, T., Mädler, L., Li, T., 2006. Toxic potential of materials at the nanolevel. Sci. $\quad 311,622-627$.

Nowack, B., Bucheli, T.D., 2007. Occurrence, behaviour, and effects of nanoparticles in the environment. Environ. Poll. 150, 5-22.

Oberdörster, G., Gelein, R.M., Ferin, J., Weiss, B., 1995. Association of particulate air pollution and acute mortality: Involvement of ultrafine particles? Inhal. Toxicol. $7,111-124$.

Oberdorster, G., Oberdorster, E., Oberdorster, J., 2005. Nanotoxicology: An emerging discipline evolving from studies of ultrafine particles. Environ. Health Perspect. $113,823-839$.

Oberholster, P.J., Botha, A.M., Cloete, E., 2005. Using a battery of bioassays, benthic phytoplankton and the AUSRIVAS method to monitor long-term coal tar contaminated sediment in the Cache la Poudre River, Colorado. Wat. Res. 39, 4913-4924.

Owens, D.E., Peppas, N.A., 2006. Opsonization, biodistribution, and pharmacokinetics of polymeric nanoparticles. Int. J. Pharmaceutics 307, 93-102.

Plumb, R.H., 1981. Procedure for handling and chemical analysis of sediment and water samples. Technical Report EPA/CE 81-1. US Army Engineer Waterways Experiment Station, Vicksburg, MS.

Powers, K.W., Brown, S.C., Krishna, V.B., Wasdo, S.C., Moudgil, B.M., Roberts, S.M., 2006. Research strategies for safety evaluation of nanomaterials, Part.VI: Characterization of nanoscale particles for toxicological evaluation. Toxicol. Sci. 90, 296-303. 
Rao, C.N.R., Cheetham, A.K., 2001. Science and technology of nanomaterials: current status and future prospects. J. Mater. Chem. 11: 2887-2894.

Roco, M.C., 2004. Nanoscale Science and Engineering: Unifying and transforming tools. AIChE J 50, 890-897.

Roco, M.C., 2005. International perspective on government nanotechnology funding in 2005. J. Nanopart. Res. 7, 707-712.

Royal Society and Royal Academy of Engineering Society, 2004. Nanoscience and Nanotechnologies: opportunities and uncertainties. The Royal Society and Royal Academy of Engineering, pp. 127.

Scott-Fordsmand, J.J., Krogh, P.H., Schaefer, M., Johansen, A., 2008. The toxicity testing of double-walled nanotubes-contaminated food to Eisenia veneta earthworms. Ecotox. Environ. Saf. 71, 616-619.

Shvendova, A.A., Castranova, V., 2003. Exposure to carbon nanotube material: Assesment of nanotube cytotoxicity using human keratinocyte cells. J. Toxicol. Environ. Health Part A. 66, 1909-1926.

Sigg, L., 1994. The regulation of trace elements in lakes: The role of sedimentation. In Buffle J, de Vitre RR, (eds), The Chemical and Biological Regulation of Aquatic Systems, 2 nd ed. Lewis, Boca Raton, FL, USA, pp 633-651.

Smith, C.J., Shaw, B.J., Handy, R.D., 2007. Toxicity of single walled carbon nanotubes on rainbow trout, (Oncorhynchus mykiss): respiratory toxicity, organ pathologies, and other physiological effects. Aquatic Toxicol. 82, 94-109.

Stegeman, J., Brouwer, M., R., DiGuilio, R., Forlin, L., Fowler, B., Sanders, B., VanHeld, P., 2001. Molecular response to environmental contamination: enzymes and protein system as indicators of chemical exposure and effect. In: R. Huggett, R. Kimerele, P.J. Mehrle, H. Bergman (eds.), Biomarkers: Biological, 
Physiological and Histological Markers of Anthropogenic Stress. Lewis, Boca Raton, FL, pp. 273-275.

Sweet, L.I., Passino-Reader, D.R., Meier, P.G., Omann, G.M., 1999. Xenobioticinduced apoptosis: significance and potential application as a general biomarker of response. Biomarkers 4, 237-253.

Thursby, G.B., Heltshe, J., Scott, K.J., 1997. Revised approach to toxicity test acceptability criteria using a statistical performance assessment. Environ. Toxicol. Chem. 16, 1322-1329.

USEPA (United States of Environmental Protection Agency) 2000. Methods for Assessing the Toxicity and Bioaccumulation of Sediments-Associated Contaminants with Freshwater Invertebrates, $2^{\text {nd }}$ Ed, EPA/600/R-99/064, Duluth, Minnesota, 55804.

Vutukuru, S.S., Chintada, S., Madhavi, K.R., Rao, J.V., Anjaneyulu, Y., 2006. Acute effects of copper on superoxide dismutase, catalase and lipid peroxidation in the freshwater teleost fish, Esomus danricus, Fish Physiol. Biochem. 32, 221-229.

Walshe, B.M., 1947. Feeding mechanism of Chironomus larvae. Nat. 160, 474.

Warheit, D.B., Borm, P.J.A., Hennes, C., Lademann, J., 2007a. Testing strategies to establish the safety of nanomaterials: Conclusions of an ECETOC workshop. Inhal. Toxicol. 19, 631-643.

Warheit, D.B., Hoke, R.A., Finlay, C., Donner, E.M., Reed, K.L., Sayes, C.M. 2007b.Development of a base set of toxicity tests using ultrafine $\mathrm{TiO}_{2}$ particles as a component of nanoparticle risk management, Toxicol. Lett. 171, 99-110.

Wang, B., Feng, W., Wang, T., Jia, G., Wang, M., Shi, J., Zhang, F., Zhao, Y., Chai, Z., 2006. Acute toxicity of nano-and micro-scale zinc powder in healthy adult mice. Toxicol. Lett.161, 115-123. 
Wang, B., Feng, W., Wang, M., Wang, T., Gu, Y., Zhu, M., Ouyang, H., Shi, J., Zhang, F., Zhao, Y., Chai, Z., Wang, H., Wang, J., 2008. Acute toxicology impact of nano-and submicro-scaled zinc oxide powder on healthy adult mice. J. Nanopart. Res. 10, 263-276.

Wiesner, M.R., Lowry, G.V., Alvarez, P., Dionysiou, D., Biswas, P., 2006. Assessing the risks of manufactured nanomaterials. Environ. Sci. Technol. 40, 4336-4345. 